\title{
Investigation on the Performance of a Wickless- Heat Pipe Using Graphene Nanofluid for Passive Cooling System
}

\author{
M.H. Kusuma ${ }^{1,2^{\star}}$, N. Putra ${ }^{1}$, A. Rosidi $^{2}$, S. Ismarwanti ${ }^{3}$, A.R. Antariksawan ${ }^{4}$, \\ T. Ardiyati ${ }^{5}$, M. Juarsa ${ }^{2}$ and T.M.I. Mahlia ${ }^{6}$ \\ ${ }^{I}$ Applied Heat Transfer Research Group, Department of Mechanical Engineering, Universitas Indonesia, \\ Kampus UI Depok 16424, Indonesia \\ ${ }^{2}$ Center for Nuclear Reactor Technology and Safety, National Nuclear Energy Agency, \\ Puspiptek Area Serpong, Tangerang Selatan 15314, Indonesia \\ ${ }^{3}$ Center for Nuclear Fuel Technology, National Nuclear Energy Agency, \\ Puspiptek Area Serpong, Tangerang Selatan 15314, Indonesia \\ ${ }^{4}$ Center for Accelerator Science and Technology, National Nuclear Energy Agency, \\ Jl. Babarsari, Yogyakarta 55281, Indonesia \\ ${ }^{5}$ Center for Nuclear Facilities Engineering, National Nuclear Energy Agency, \\ Puspiptek Area Serpong, Tangerang Selatan 15314, Indonesia \\ ${ }^{6}$ School of Information, Systems and Modelling, Faculty of Engineering and Information Technology, \\ University of Technology Sydney, NSW, 2007, Australia
}

\section{ARTICLE INFO}

Article history:

Received 12 July 2017

Received in revised form 10 April 2019

Accepted 28 June 2019

Keywords:

Nano graphene

Heat pipe

Nano fluid

Passive cooling system

Spent fuel pool

\begin{abstract}
A B S T R A C T
To enhance the thermal safety in case of station blackout, a wickless-heat pipe is proposed as an alternative passive cooling system technology to remove decay heat generation in the nuclear spent fuel storage pool. The objectives of this research are to investigate the heat transfer phenomena in vertical straight wicklessheat pipe using Graphene nanofluid working fluid and to study the effect of Graphene nanofluid on the vertical straight wickless-heat pipe thermal performance. The investigation was conducted in 6 meters height and $0.1016 \mathrm{~m}$ inside diameter of vertical straight wickless-heat pipe. In this research, the Graphene nanofluid with $1 \%$ of weight concentration was used as working fluid. The effect of working fluid filling ratio, evaporator heat load, and coolant volumetric flow rate on the water jacket were studied. The results showed that the heat transfer phenomena, which were indicated by an overshoot, zigzag, and stable state, were observed. Based on thermal resistance obtained, it was shown that the vertical straight wickless-heat pipe charged with the Graphene nanofluid has a lower thermal resistance compared to one with demineralized water. The thermal resistance of vertical straight wickless-heat pipe using Graphene nanofluid and demineralized water were $0.015{ }^{\circ} \mathrm{C} / \mathrm{W}$ and $0.016{ }^{\circ} \mathrm{C} / \mathrm{W}$, respectively. While the best thermal performance was achieved at a filing ratio of $80 \%$, higher heat load, and higher coolant volumetric flow rate. It can be concluded that Graphene nanofluid could enhance the thermal performance of vertical straight wickless-heat pipe.
\end{abstract}

(C) 2019 Atom Indonesia. All rights reserved

\section{INTRODUCTION}

A Station blackout (SBO) which caused a severe accident at the Fukushima Daiichi nuclear power station has become a valuable lesson learnt for the safety design of nuclear power plants around the world. The passive cooling system should be

\footnotetext{
*Corresponding author.

E-mail address: luluikal@batan.go.id

DOI: https://doi.org/10.17146/aij.2019.761
}

considered in the design of safety system of nuclear plants to avoid the severe accident.

One of the passive cooling systems technology that can be applied to remove the decay heat generation is heat pipe. Because of its lowest thermal resistance, the heat pipe functions as an efficient heat dissipation device [1]. So far, the heat pipe is used as cooling systems in the electronic equipment [2], air preheating [3], electric vehicle application [4]; solar desalination [5]; solar water 
heater [6]; nuclear seawater desalination [7]; and as heat recovery for air conditioning, ventilation, and solar application [8].

In the nuclear field, the heat pipe is considered and proposed to be used as a passive cooling system, such as loop heat pipe [9-12]; two-phase closed thermosyphon loop [12,13]; hybrid heat pipe [14-17]; variable conductance heat pipe [18]; heat pipe radiator [19]; sodium heat pipe [20]; and vertical straight wickless-heat pipe [21-24]. The results of heat pipe investigation showed that heat pipe with demineralized water working fluid has good thermal performance to remove the heat generation and it could be proposed to be used as passive cooling system in nuclear installation when accident occurred.

On the other hand, in order to increase the thermal performance of the vertical straight wickless-heat pipe, the use of nanofluid as working fluid in the heat pipe has also been investigated by many researchers. Putra et al. used nanofluid as the heat pipe working fluid. Their results showed that the use of nanofluid could increase the thermal performance of heat pipes for removing the heat from electronic devices [25,26].

Graphene was used as a nanofluid material. Graphene nanofluid was also one of the chosen heat pipes working fluid to increase the heat pipe thermal performance. Graphene in nano particles is easy to be synthesized and it has longer suspension time because of its stability, also higher thermal conductivity, reduction in inventory of heat transfer fluid, and significant energy saving [27]. Graphene is a flat monolayer of carbon atoms tightly packed into a two-dimensional honeycomb lattice. The particular 2D structure leads to high electric and thermal conductivity, providing for easy motion of the charge carriers [28,29]. The use of Graphene nanoparticles in pool boiling would enhance the boiling heat transfer and the critical heat flux [30]. Graphene nanofluid has special features, such as increased thermal conductivity, enhancement of heat transfer ability and enhanced stability over other nanoparticles (i.e. electrical properties), that are essential for various engineering applications [31].

Sadeghinezad et al. conducted an experimental investigation to examine the thermal performance of a sintered wicked heat pipe using aqueous Graphene nanoplatelets nanofluid. Their result showed that inclination angle and nanoparticle concentration in the working fluid strongly affected the heat transfer performance of heat pipe [32]. Kim et al. had studied the thermal performances of Graphene oxide/water nanofluid heat pipes with a screen mesh wick. The wall temperature of the Graphene oxide/water nanofluid-filled heat pipe was found to be lower than the heat pipe operated using water. Moreover, the heat pipes charged with Graphene oxide/water nanofluid have lower evaporator thermal resistances of $25 \%$ compared to the water nanofluid [30]. Tharayil et al. conducted an experiment to analyze the thermal performance of the Long Heat Pipe (LHP) with water and Graphene-water nanofluid as working fluid. Their result showed that the nanofluid improved the thermal performance of Long Heat Pipe LHP [31]. Maryam Shafahi et al. conducted analytical modelling on the influence of nano fluid $\mathrm{Al}_{2} \mathrm{O}_{3}, \mathrm{CuO}$, and $\mathrm{T}_{\mathrm{i}} \mathrm{O}_{2}$ on the cylindrical heat pipe thermal performance. The effect of nanofluids weight concentration was investigated. The analytical modelling result showed that the smaller particles have a larger effect on the heat transfer of heat pipe, because it was more uniformly distributed in the heat pipe [33].

Based on the literature study, it can be said that the utilization of Graphene nanofluid as vertical straight wickless-heat pipe working fluid has never been investigated by any other researchers. Then, the preliminary research on the using of Graphene nanofluid as working fluid for vertical straight wickless-heat pipe has been performed. The preliminary investigation was only focused on the effect of heat load given to the heat pipe evaporator with $1 \%$ Graphene nanofluid weight concentration. Our preliminary result showed that the use of Graphene nanofluid could enhance the thermal performance of the heat pipe to transfer heat from the heat source to the heat sink [34].

As a basic knowledge to know the effect of graphene nanofluid as heat pipe working fluid to increase the thermal performance of vertical straight wickless-heat pipe, the objectives of this research are to investigate the heat transfer phenomena in vertical straight wickless-heat pipe using Graphene nanofluid working fluid and to study the effect of Graphene nanofluid on the vertical straight wicklessheat pipe thermal performance. The experimental investigation was conducted in order to study the effect of Graphene nanofluid on the heat pipe thermal performance with different operation parameters, such as heat pipe filling ratio, evaporator heat load, and coolant volumetric flow rate on the condenser's water jacket.

The obtained results from this investigation are expected to contribute to the development of thermal management and safety of the nuclear spent fuel storage pool (SFSP), especially for the SFSP of G.A. Siwabessy research reactor (RSG-GAS), against an Station Blackout (SBO) event.

\section{EXPERIMENTAL METHODS}

\section{Experimental setup}

The experimental setup can be seen in Fig. 1. The pipe was made of Copper tube with a length of 
$6 \mathrm{~m}$, inside diameter of $0.1016 \mathrm{~m}$, and outside diameter of $0.1031 \mathrm{~m}$. The vertical straight wicklessheat pipe consists of three sections, i.e. evaporator, adiabatic and condenser, with same length of $2 \mathrm{~m}$.

The evaporator section, which is in the lowest part, is covered by the electric band heater with a maximum power of $2800 \mathrm{~W}$. This heater is to simulate the heat generation from 256 of spent fuel for 4-16 years stored in the SFSP of RSG-GAS. With the heat generation of $4.08-10.20 \mathrm{~W} / \mathrm{spent}$ fuel, then the heat loads of the evaporator were varied to $1000 \mathrm{~W}, 1500 \mathrm{~W}, 2000 \mathrm{~W}$, and $2500 \mathrm{~W}$. An analogue voltage regulator was used to control the heat load of evaporator section. A digital clamp meter was used for measuring the voltage of the heater. Graphene nanofluid with $1 \%$ of weight concentration was used as working fluid. Using only the graphene weight concentration of $1 \%$ in the working fluid used, it is assumed that the boiling temperature of demineralized water containing $1 \%$ graphene does not change and still has the boiling temperature of pure demineralized water without nano graphene mixture. Considering the expensive price of graphene and the homogeneous dispersion of the graphene in the fluid, graphene concentration was not varied in this study. The graphene concentration of $1 \%$ weight is chosen only to determine the effect of adding graphene on the heat pipe thermal performance.

Graphene nanoplatelets (pure carbon nano tube) were dissolved into the demineralized water. The physical and chemical properties of the graphene are as follows: black granules/powder, carbon content more than $99 \%$, diameters of $10-30 \mathrm{~nm}$, width less than $2 \mu \mathrm{m}$, thickness less than $2 \mu \mathrm{m}$, density of $2.2 \mathrm{~g} / \mathrm{cm}^{3}$, specific surface area of $300 \mathrm{~m}^{2} / \mathrm{g}$, relative gravity of $2.0-2.25 \mathrm{~g} / \mathrm{cm}^{3}$, and thermal conductivity of $3000 \mathrm{~W} / \mathrm{m}$.K. The demineralized water used is made by Bratachem and it has conductivity of $<2 \mu \mathrm{S} / \mathrm{cm}$ (at temperature of $25^{\circ} \mathrm{C}$ ). To compare with our previous results and results from other researchers $[21,23,24,35-40]$, the graphene charged to the evaporator with various filling ratios of $40 \%, 60 \%$, and $80 \%$. The filling ratio is defined as the ratio of filled liquid to the volume of the evaporator section.

The condenser section was covered by a water jacket. As the heat absorber, the water jacket was connected to a circulating thermostatic bath that controlled the volumetric flow rate and temperature of the coolant at the inlet section of the water jacket. Water was used as a coolant in the water jacket and circulated with counter flow direction. In order to determine the effect of coolant volumetric flow rate on heat absorption in the condenser, the coolant volumetric flow rates were varied at $4 \mathrm{~L} / \mathrm{min}$,
$6 \mathrm{~L} / \mathrm{min}$, and $8 \mathrm{~L} / \mathrm{min}$. These coolant flow rates are to simulate the range of natural circulation flow rate resulted from a cooling water tank placed at about 3-5 meters above the condenser. This natural circulation is assumed to be an option of condenser cooling system. To control the inlet and outlet of coolant flow rate, 2 manual flow meters with uncertainties of $\pm 4 \%$ were placed in the water jacket. The coolant temperature was kept constant at the coolant ambient temperature of $26^{\circ} \mathrm{C}$.

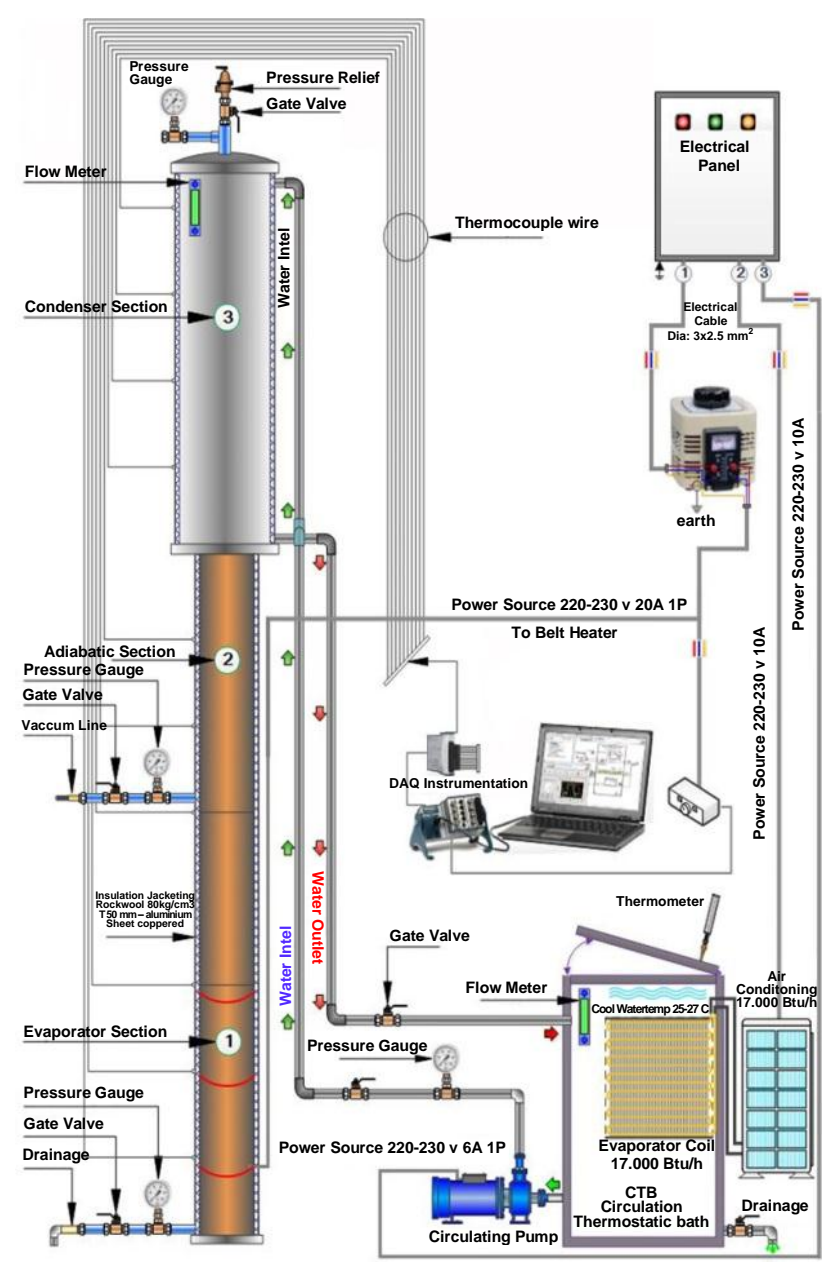

Fig. 1. Experimental setup $[23,24]$.

Before working fluid was charged to the vertical straight wickless-heat pipe, non-condensable gas inside the vertical straight wickless-heat pipe was removed using a vacuum pump. The vacuum process was also to set the initial pressure inside the vertical straight wickless-heat pipe. The initial pressure value was set to $-74 \mathrm{~cm} \mathrm{Hg}$ and was controlled using 3 manual pressure gauges which were installed in the evaporator, adiabatic section, and condenser sections. The uncertainties of manual pressure gauge was $\pm 1.55 \mathrm{~cm} \mathrm{Hg}$. To keep the safety of a heat pipe system, a pressure relief valve was installed at the top of the condenser section to control the operating pressure of the steam. 
The experimental temperature data were recorded using the temperature module of a National Instrument data acquisition system that connected to a Lab VIEW virtual instrument program. The placement of thermocouples on the experimental test section is shown in Fig. 2. Fifteen channels of $\mathrm{K}$ - type thermocouples with accuracy of $\pm 0.1{ }^{\circ} \mathrm{C}$ were placed on the heat pipe outside wall: 3 thermocouples on the evaporator outside wall, 3 thermocouples on the adiabatic outside wall, 3 thermocouples on the condenser outside wall, 1 thermocouple on the evaporator isolation wall, 1 thermocouple on the adiabatic isolation wall, 1 thermocouple on the coolant inlet, 1 thermocouple on the coolant outlet, 1 thermocouple on the circulating thermostatic bath, and 1 thermocouple for measuring the ambient temperature.

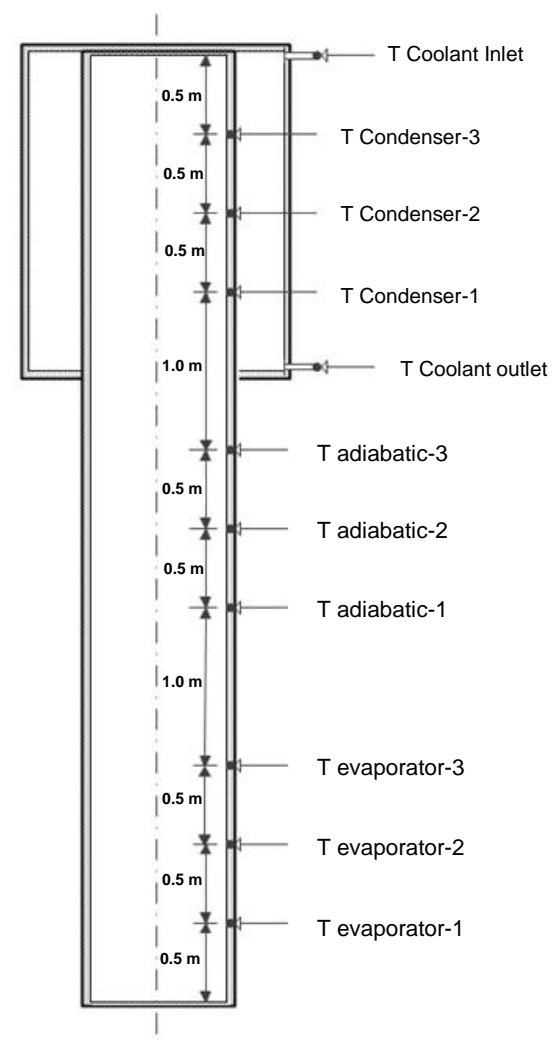

Fig. 2. Placement of thermocouples $[23,24]$.

\section{Preparation of graphene nanofluid}

Graphene nanofluid with $1 \%$ of weight concentration means that there was a $10 \mathrm{gr}$ of nano Graphene in $1000 \mathrm{~mL}$ of nanofluid. A digital scale with super hybrid sensor was used to scale the weight of nanographene. A sonification process was conducted to dissolve the mixture of nanographene and demineralized water. The sonification process was conducted for 4 hours. The preparation process to dissolve the mixture is described in Fig. 3.

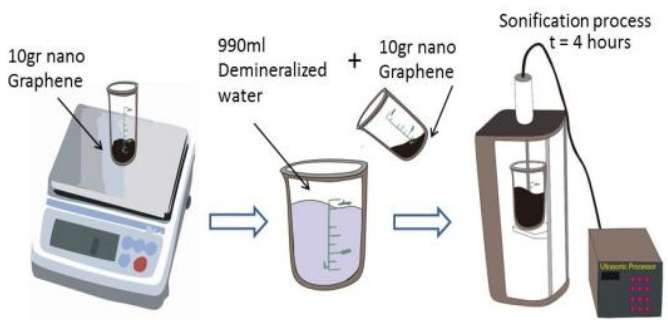

Fig. 3. Preparation process to dissolve nanographene and demineralized water nanofluid [34]

\section{RESULTS AND DISCUSSION \\ Transient temperature distribution}

The measurement of vertical straight wickless-heat pipe transient temperatures with variation of filling ratio, heat load, and coolant volumetric flow rate were depicted in Figs. 4 to 12.

Figures 4 to 6 show the measurements of transient temperature distribution on the outside wall of the vertical straight wickless-heat pipe at filling ratio of $40 \%$; heat loads of $1000 \mathrm{~W}, 1500 \mathrm{~W}$, $2000 \mathrm{~W}$, and $2500 \mathrm{~W}$ for coolant volumetric flow rates of $4 \mathrm{~L} / \mathrm{min}, 6 \mathrm{~L} / \mathrm{min}$, and $8 \mathrm{~L} / \mathrm{min}$, respectively.

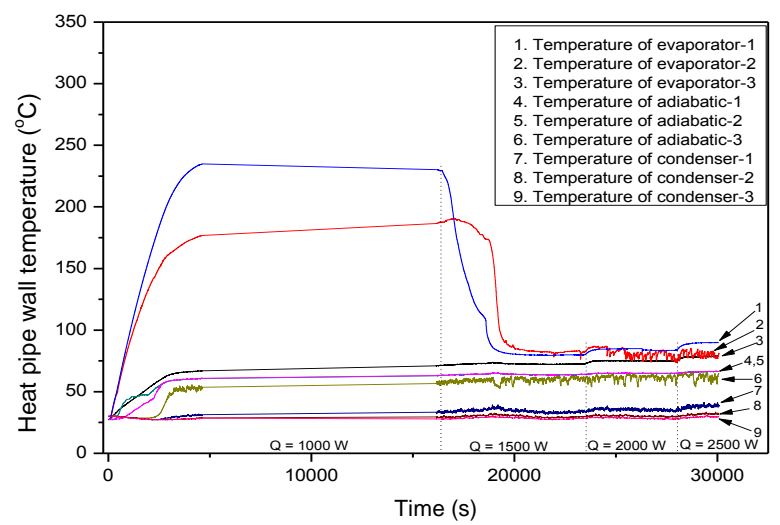

Fig. 4. The transient temperature at a filling ratio of $40 \%$ and coolant volumetric flow rate of $4 \mathrm{~L} / \mathrm{min}$ with variation of heat loads.

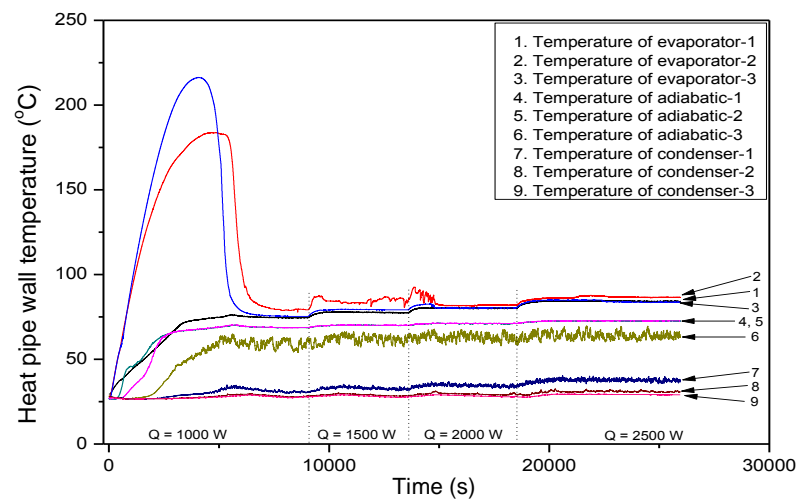

Fig. 5. The transient temperature at a filling ratio of $40 \%$ and coolant volumetric flow rate of $6 \mathrm{~L} / \mathrm{min}$ with variation of heat loads. 


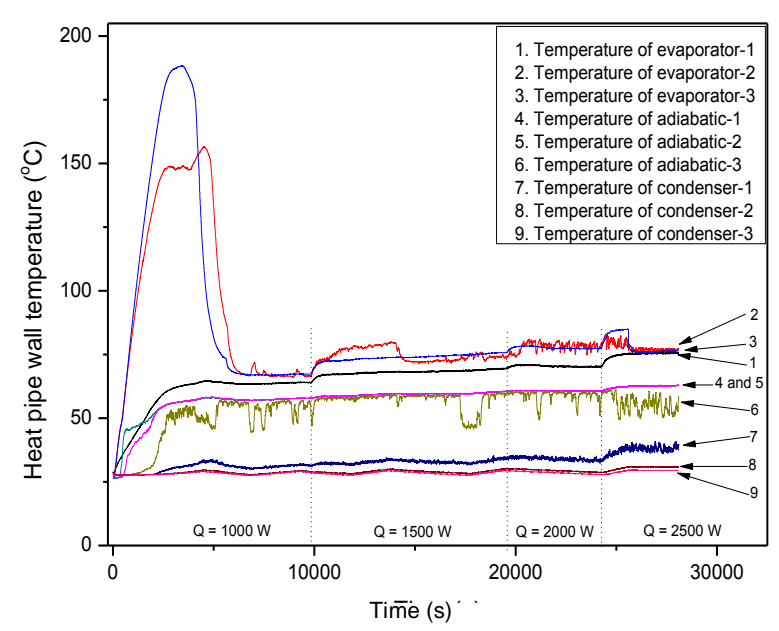

Fig. 6. The transient temperature at a filling ratio of $40 \%$ and coolant volumetric flow rate of $8 \mathrm{~L} / \mathrm{min}$ with variation of heat loads.

It can be seen from those figures, the overshoot, zigzag, and stable pattern phenomena were observed for variations of heat load and coolant volumetric flow rate. Those are similar phenomena as found in the previous investigation using small scale vertical straight wickless-heat pipe [21].

The heat load supplied to evaporator boiled the Graphene nanofluid rapidly. The evaporator temperature increased significantly due to heat received. The peak temperature in this state was called overshoot phenomenon. The vapor then rises to condenser through adiabatic section. The vapor released the latent heat, which is absorbed by coolant in the water jacket, and the vapor condensed. The condensate as a result of condensation process remained in the condenser and not flew down to the evaporator. After overshoot occurred, the condensate flew down gravitationally to the evaporator. It could be seen that the evaporator temperature decreased when the condensate started flowing from the condenser to the evaporator. This condition marked the start of natural circulation in the pipe. After that, the evaporator temperature formed a zigzag temperature pattern when natural circulation in the heat pipe was started circulating. The stable phenomenon of temperature distribution was achieved when the zigzag phenomenon ended. At that time, the natural circulation in the heat pipe was fully established. The stable phenomenon was signed by lower difference between evaporator and condenser temperature.

Figures [4-6] also show that, for variations of heat load, higher heat load affects the increasing of evaporator, condenser, and adiabatic temperatures until isothermal condition is reached. It can be seen that the increasing of heat load after stable temperature distribution achieved would not affect the recurrent of overshoot phenomena, but only on recurrence of zigzag and stable phenomena and the increasing of the overall heat pipe temperature. In accordance with the increase of the heat load, the evaporator wall temperature increased as well and resulted more heat transferred to Graphene nanofluid in the evaporator region. It caused the Graphene nanofluid boiling more rapidly. Meanwhile, the smaller the heat load applied to the evaporator, the lower the latent heat transferred from the condenser. The rapid boiling process increased the evaporation rate, and produced more vapor to be transported to the condenser. In the condenser, the heat of vapor was absorbed by the cooling water in the water jacket. The vapor was condensed and the condensate, which was accumulated on the inner wall surface of the condenser, fell down back to the evaporator. When stable condition occurs in constant heat load, for variations of coolant volumetric flow rate, higher coolant volumetric flow rate decreased the peak of overshoot temperature and the temperature difference between evaporator and condenser. A higher coolant volumetric flow rate also accelerates the achievement of the natural circulation. It can be seen from the figure that the average temperature difference between evaporator and condenser at filling ratio $40 \%$ for variation of coolant volumetric flow rates of $4 \mathrm{~L} / \mathrm{min}, 6 \mathrm{~L} / \mathrm{min}$, and $8 \mathrm{~L} / \mathrm{min}$ are $52.0{ }^{\circ} \mathrm{C}, 49.8{ }^{\circ} \mathrm{C}$, and $43.8^{\circ} \mathrm{C}$, respectively.

Figures 7 to 9 show the measurement of transient temperature distribution on the outside wall of the evaporator and the condenser at filling ratios of $60 \%$; heat load of $1000 \mathrm{~W}, 1500 \mathrm{~W}$, $2000 \mathrm{~W}$, and $2500 \mathrm{~W}$; and coolant volumetric flow rates of $4 \mathrm{~L} / \mathrm{min}, 6 \mathrm{~L} / \mathrm{min}$, and $8 \mathrm{~L} / \mathrm{min}$.

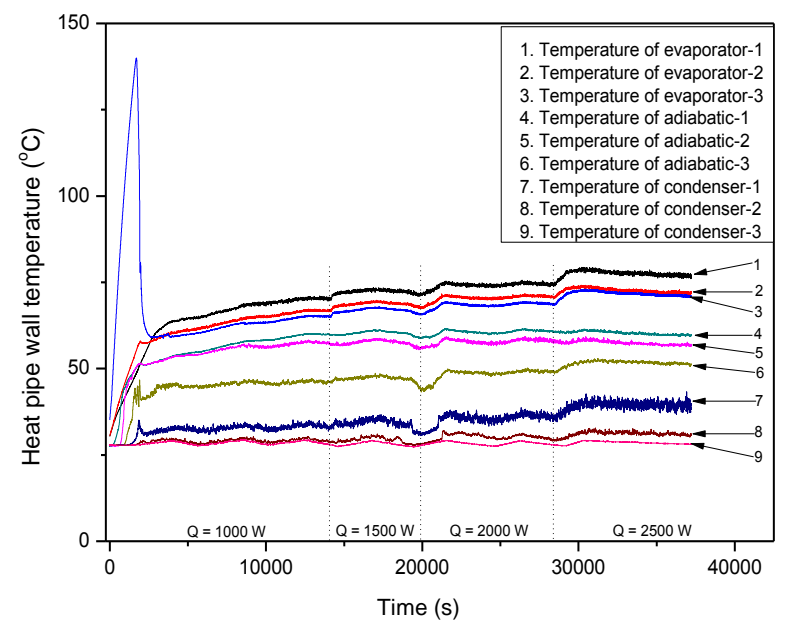

Fig. 7. The transient temperature at a filling ratio of $60 \%$ and coolant volumetric flow rate of $4 \mathrm{~L} / \mathrm{min}$ with variation of heat loads. 


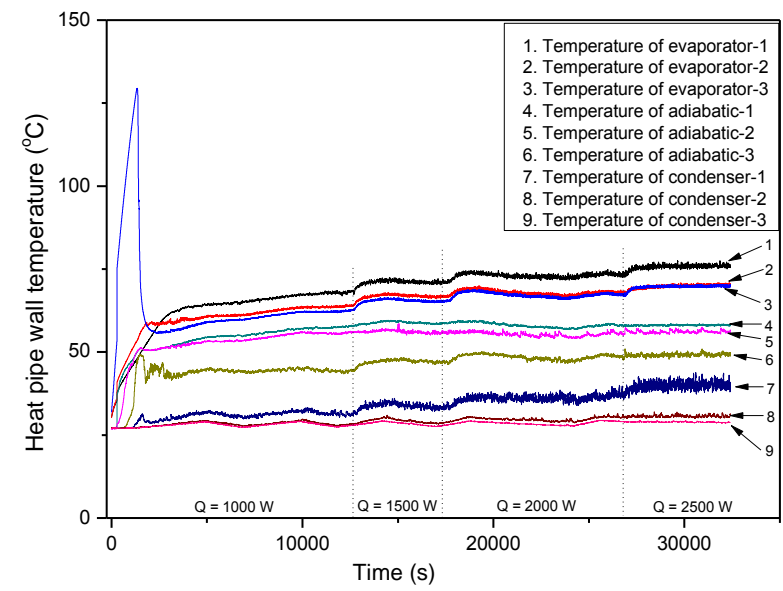

Fig. 8. The transient temperature at a filling ratio of $60 \%$ and coolant volumetric flow rate of $6 \mathrm{~L} / \mathrm{min}$ with variation of heat loads.

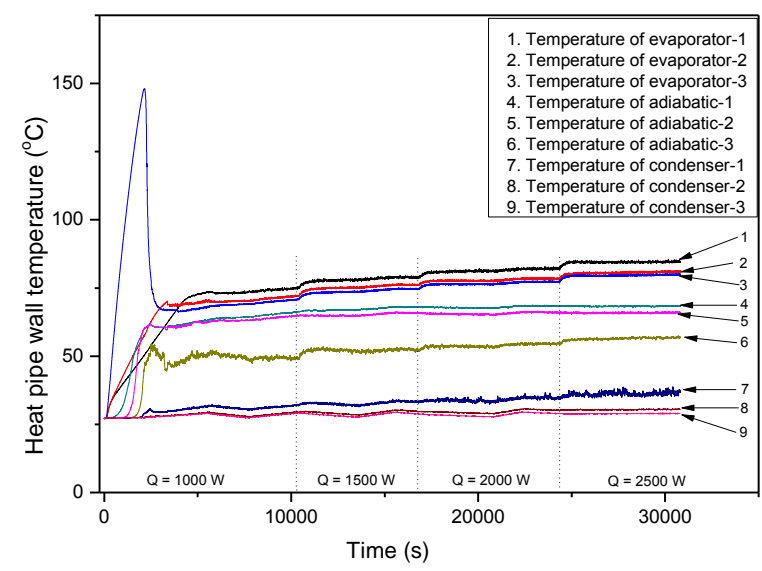

Fig. 9. The transient temperature at a filling ratio of $60 \%$ and coolant volumetric flow rate of $8 \mathrm{~L} / \mathrm{min}$ with variation of heat loads.

It can be seen from Figs. 7 to 9 that the temperature profile and phenomena observed at filling ratio $60 \%$ is identical with the filling ratio of $40 \%$. For all heat load and coolant volumetric flow rates variation, the overshoot temperature peak that was obtained, was lower than at filling ratio $40 \%$. As the filling ratio increases, the liquid in contact with the heated wall increases causing the heat transfer from evaporator to working fluid and evaporation rate increase as well. It can be seen from the figures that the average temperature differences between evaporator and condenser at filling ratio of $60 \%$ and for variation of coolant volumetric flow rates of $4 \mathrm{~L} / \mathrm{min}, 6 \mathrm{~L} / \mathrm{min}$, and $8 \mathrm{~L} / \mathrm{min}$ are $55.8{ }^{\circ} \mathrm{C}, 50.8{ }^{\circ} \mathrm{C}$, and $46.4{ }^{\circ} \mathrm{C}$, respectively.

Figures 10 to 12 show the measurement of transient temperature distribution at the outside wall of the evaporator and the condenser at filling ratio of $80 \%$ with heat loads of $1000 \mathrm{~W}, 1500 \mathrm{~W}, 2000 \mathrm{~W}$, and $2500 \mathrm{~W}$; and coolant volumetric flow rates of $4 \mathrm{~L} / \mathrm{min}, 6 \mathrm{~L} / \mathrm{min}$, and $8 \mathrm{~L} / \mathrm{min}$.

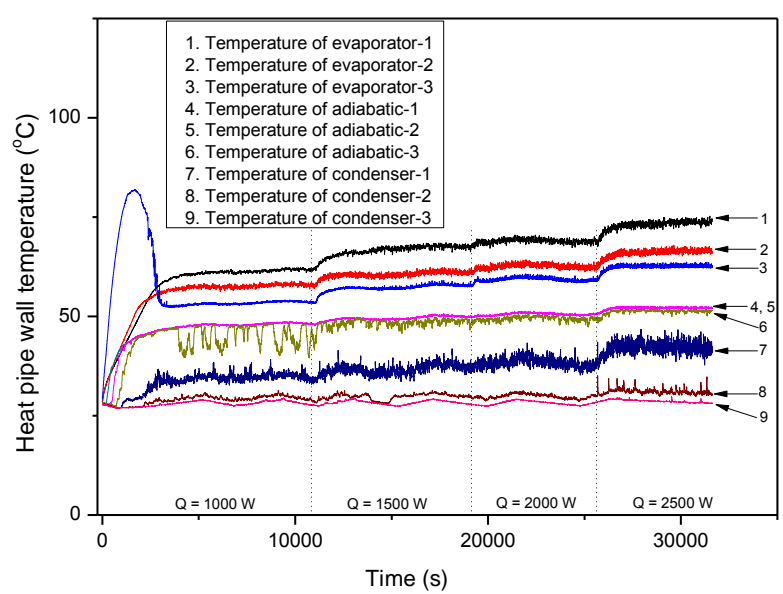

Fig. 10. The transient temperature at a filling ratio of $80 \%$ and coolant volumetric flow rate of $4 \mathrm{~L} / \mathrm{min}$ with variation of heat loads.

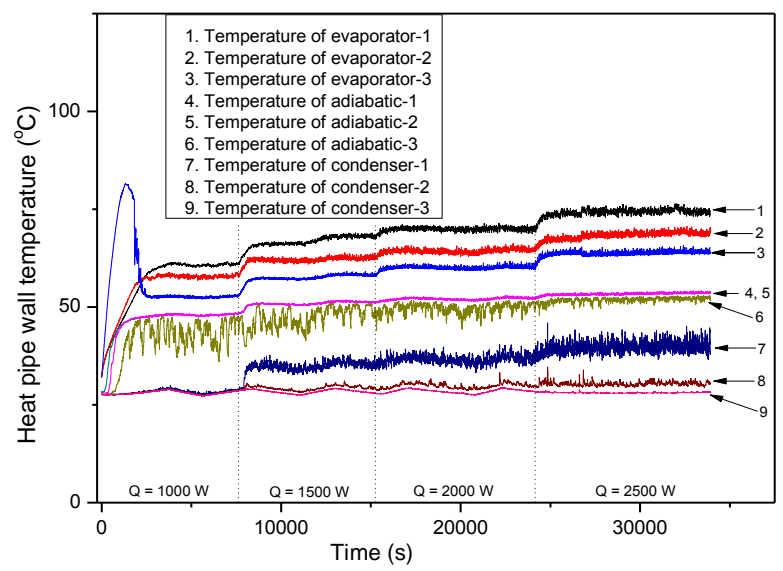

Fig. 11. The transient temperature at a filling ratio of $80 \%$ and coolant volumetric flow rate of $6 \mathrm{~L} / \mathrm{min}$ with variation of heat loads.

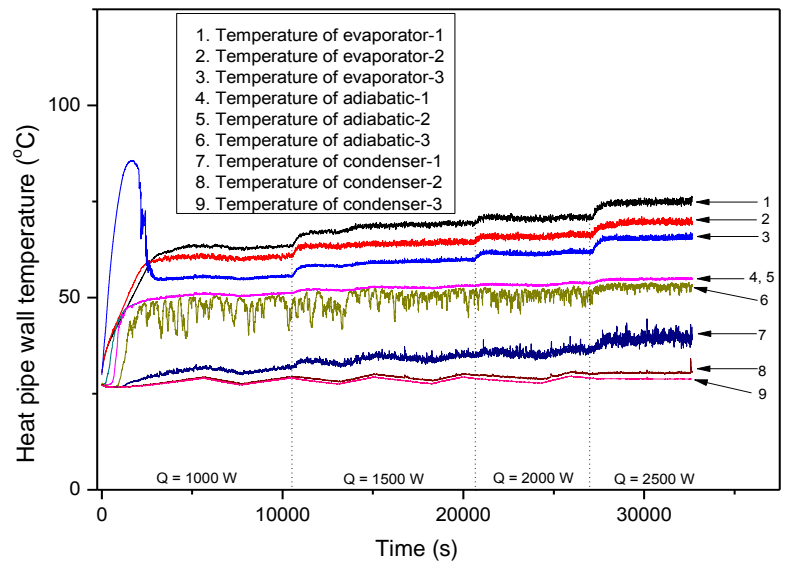

Fig. 12. The transient temperature at a filling ratio of $80 \%$ and coolant volumetric flow rate of $8 \mathrm{~L} / \mathrm{min}$ with variation of heat loads.

Figures 10 to 12 show that filling ratio of $80 \%$ that resulted similar phenomena and temperature profile as of filling ratios of $40 \%$ and $60 \%$. Though, at filling ratio of $80 \%$, the peak of overshoot temperature was lower than at filling ratios of $40 \%$ and $60 \%$. The influences of the 
coolant volumetric flow rate and heat load on the transient temperature profile were obtained that a higher coolant volumetric flow rate decreased the evaporator and condenser temperatures, and a higher applied heat load increased the evaporator and the condenser temperatures.

It can be seen from Figs. 10 to 12 that the average temperature differences between evaporator and condenser at filling ratio $80 \%$ for variation of coolant volumetric flow rates of $4 \mathrm{~L} / \mathrm{min}, 6 \mathrm{~L} / \mathrm{min}$, and $8 \mathrm{~L} / \mathrm{min}$ are $37{ }^{\circ} \mathrm{C}, 36.13{ }^{\circ} \mathrm{C}$, and $33.28{ }^{\circ} \mathrm{C}$, respectively.

\section{Steady state temperature distribution}

The steady state temperature distribution analysis below are conducted for the variation of heat load and filling ratio with constant coolant volumetric flow rate of $8 \mathrm{~L} / \mathrm{min}$. The variation of the coolant volumetric flow rate is not discussed because the transient temperature results obtained show that, for a constant specified heat load, the coolant volumetric flow rate of $8 \mathrm{~L} / \mathrm{min}$ has the lowest temperature difference between the evaporator and the condenser and resulted the lower thermal resistance of vertical straight wickless-heat pipe. As well known, the higher thermal performance of vertical straight wicklessheat pipe will be achieved on lower thermal resistance.

Figure 13 shows the wall temperature distribution of the vertical straight wickless-heat pipe with various evaporator heat loads $(1000 \mathrm{~W}$, $1500 \mathrm{~W}, 2000 \mathrm{~W}$ and $2500 \mathrm{~W}$ ).

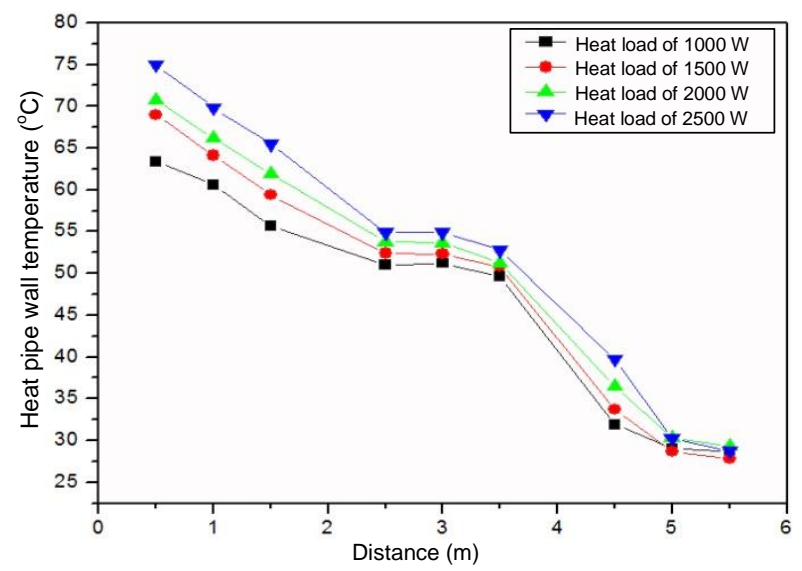

Fig. 13. Steady state temperature distribution at coolant volumetric flow rate of $8 \mathrm{~L} / \mathrm{min}$, filling ratio of $80 \%$, and varied heat loads.

It is shown in Fig. 13 that the steady state temperature distribution has similar pattern for each heat load given. For variation of heat load of
$1000,1500,2000$ and $2500 \mathrm{~W}$, the temperature differences between evaporator and condenser were $30.02{ }^{\circ} \mathrm{C}, 34.07{ }^{\circ} \mathrm{C}, 34.47{ }^{\circ} \mathrm{C}$, and $37.14{ }^{\circ} \mathrm{C}$, respectively. It can be seen that the increasing of heat load increases the temperature difference between the evaporator and the condenser.

Figure 14 shows the wall temperature distribution of the pipe for filling ratio variations at $40 \%, 60 \%$ and $80 \%$ with the heat load of $2500 \mathrm{~W}$.

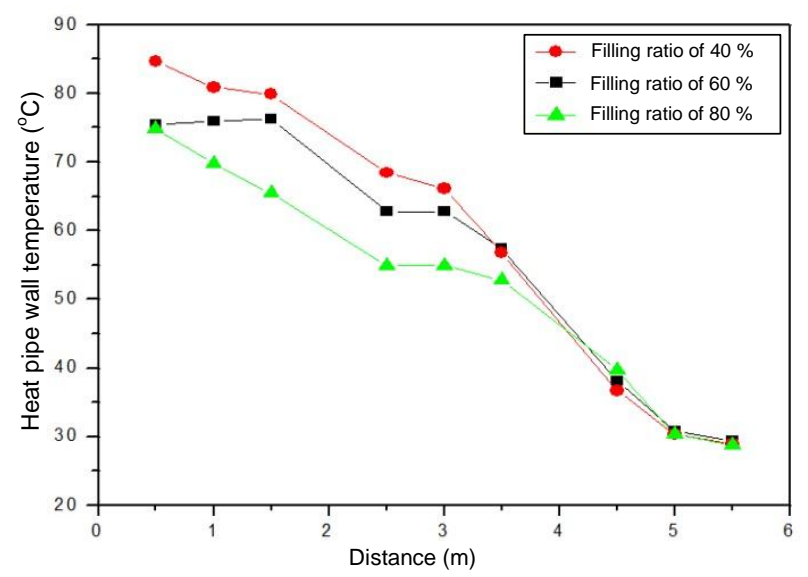

Fig. 14. Steady state temperature distribution at heat load of $2500 \mathrm{~W}$ and coolant volumetric flow rate $8 \mathrm{~L} / \mathrm{min}$, with various filling ratios

From Fig. 14, it can be seen that the temperature differences between evaporator and condenser were $49.80{ }^{\circ} \mathrm{C}, 43.24{ }^{\circ} \mathrm{C}$, and $37.08{ }^{\circ} \mathrm{C}$ for the filling ratio of $40 \%, 60 \%$ and $80 \%$, respectively. The lowest temperature difference between the evaporator and the condenser is achieved when filling ratio of $80 \%$ is charged in the evaporator pool. It can be remarked that the increasing of filling ratio decreases the temperature difference between evaporator and condenser. The increasing of filling ratio increases the evaporation rate and heat transfer from the evaporator wall to the working fluid because more evaporator's wall surface is in contact with the working fluid, which is in turn due to more rapid establishment of natural circulation inside the heat pipe than with the filling ratios of $40 \%$ and $60 \%$. The rapid natural circulation process inside the vertical straight wickless-heat pipe accelerates the heat removal in the condenser section. It also accelerates the condensate to flow back into the evaporator causing the evaporator temperature to be lower.

\section{Thermal resistance}

The thermal resistance of vertical straight wickless-heat pipe using Graphene nanofluid as working fluid is shown in Fig. 15. 


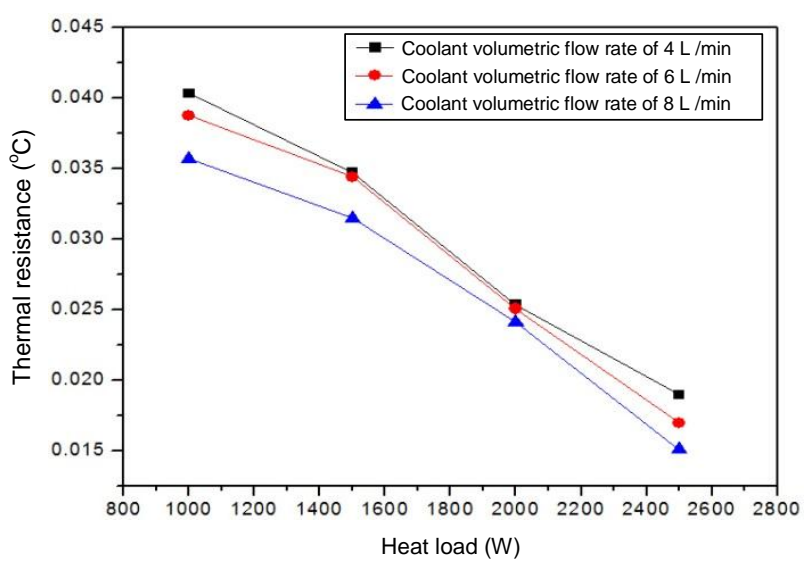

Fig. 15. Thermal resistance with Graphene nanofluid at filling ratio of $80 \%$ with various coolant volumetric flow rates and heat loads

Figure 15 shows that the thermal resistance tends to decrease as the heat load and the coolant volumetric flow rate increase. The lowest thermal resistance is $0.015{ }^{\circ} \mathrm{C} / \mathrm{W}$. The lowest thermal resistance is achieved when vertical straight wickless-heat pipe is operated at filling ratio of $80 \%$, heat load of $2500 \mathrm{~W}$, and water jacket coolant volumetric flow rate of $8 \mathrm{~L} / \mathrm{min}$.

In the previous investigation [23,24], using demineralized water as working fluid the lowest thermal resistance was $0.16{ }^{\circ} \mathrm{C} / \mathrm{W}$ at the filling ratio of $80 \%$, the evaporator heat load of $2500 \mathrm{~W}$, the water jacket coolant volumetric flow rate of $8 \mathrm{~L} / \mathrm{min}$, the coolant temperature of $26{ }^{\circ} \mathrm{C}$, and the initial pressure of $-74 \mathrm{~cm} \mathrm{Hg}$.

Comparison of these two cases is shown in Fig 16.

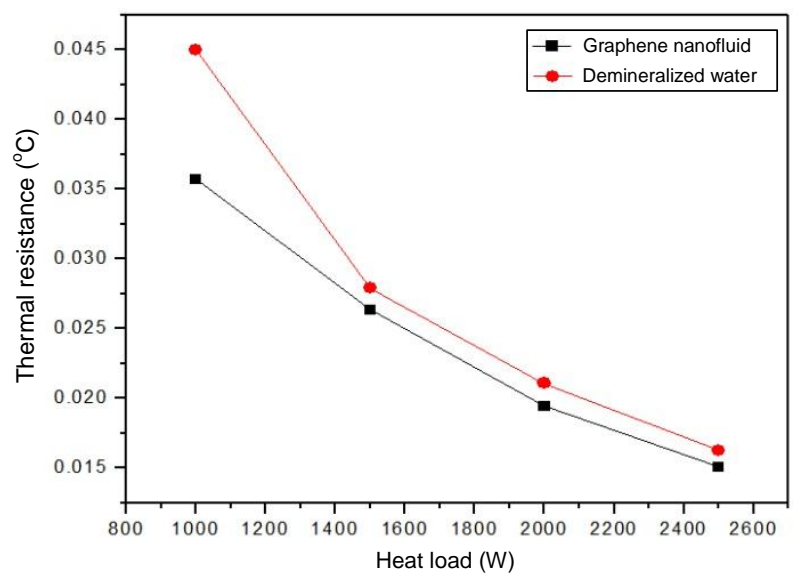

Fig. 16. Comparison of vertical straight wickless-heat pipe thermal resistance using Graphene nanofluid and demineralized water working fluid.

In both cases, the thermal resistance decreases with the increasing of the heat load applied to the evaporator and with the increasing of the coolant volumetric flow rate. Figure 16 shows also that the vertical straight wickless-heat pipe thermal resistance using Graphene nanofluid has lower thermal resistance. This can happen because the addition of Graphene nano particle in working fluid causes more frequent collisions of among nanoparticle and results in increasing creation of small bubbles. Such Brownian motion of nanoparticles increases the effect of convection on the evaporator and the condenser. On the other hand, the use of nanographene also improves the thermal conductivity and convective heat transfer coefficient of working fluid in vertical straight wickless-heat pipe, enhances heat transfer ability and stability over other nanoparticles. In overall, the use of nanographene improves the thermal performance of the heat pipe. This investigation results are in agreement with the results obtained by other researchers $[28,30,34]$. The thermal resistance of vertical straight wickless-heat pipe using Graphene nanofluid obtained was compared with other researchers result. Other researches provided the vertical straight heat pipe thermal resistances around $0.12-0.28^{\circ} \mathrm{C} / \mathrm{W}[21,41-45]$.

Based on the thermal performance results, vertical straight wickless-heat pipe is a good solution to increase the safety of the nuclear SFSP during SBO. This technology can be proposed to be applied as an alternative emergency passive cooling system in SFSP of the RSG-GAS research reactor.

\section{CONCLUSION}

The use of Graphene nanofluid as working fluid in a vertical straight wickless-heat pipe was investigated experimentally. The heat transfer phenomena obtained in the vertical straight wickless-heat pipe showed overshoot, zigzag, and stable regions. The use of vertical straight wicklessheat pipe will result in the lowest thermal resistance when it was operated at filling ratio of $80 \%$, higher heat load, and higher coolant volumetric flow rate.

The thermal resistance of vertical straight wickless-heat pipe using Graphene nanofluid and demineralized water were $0.015{ }^{\circ} \mathrm{C} / \mathrm{W}$ and $0.016^{\circ} \mathrm{C} / \mathrm{W}$ respectively. The best thermal performance was achieved at higher evaporator heat load, the filing ratio of $80 \%$, and higher coolant volumetric flow rate. The experimental result showed that the vertical straight wickless-heat pipe charged with Graphene nanofluid as working fluid had higher thermal performance compared with one charged with demineralized water.

Considering the thermal performance of the vertical straight wickless-heat pipe, it can be proposed to be used as an alternative emergency passive cooling system in nuclear spent fuel storage 
pool, where the cooling water temperature is not too high as in the RSG-GAS research reactor.

\section{ACKNOWLEDGMENT}

The authors would like to express their gratitude to DRPM Universitas Indonesia for providing funding to this research through the "PITTA 2017" scheme.

\section{REFERENCES}

1. D. Reay, R. McGlen and P. Kew, Heat Pipes: Theory, Design and Applications, ButterworthHeinemann (2013) 1.

2. Y.-W. Chang, C.-H. Cheng, J.-C. Wang et al., Energy Convers. Manag. 49 (2008) 3398.

3. L.L. Vasiliev, Appl. Therm. Eng. 25 (2005) 1.

4. N. Putra, B. Ariantara and R.A. Pamungkas, Appl. Therm. Eng. 99 (2016) 784.

5. M.H. Kusuma, N. Putra and R.E. Respati, Int. J. Technol. 9 (2018) 297.

6. B.M. Ziapour and M.B. Khalili, Energy Convers. Manag. 129 (2016) 54.

7. H. Jouhara, V. Anastasov and I. Khamis, Desalination 249 (2009) 1055.

8. D. Jafari, A. Franco, S. Filippeschi et al., Renew. Sustain. Energy Rev. 53 (2016) 575.

9. Z. Xiong, H. Gu, M. Wang et al., Nucl. Eng. Des. 280 (2014) 262.

10. Z. Xiong, M. Wang, H. Gu et al., Ann. Nucl. Energy 83 (2015) 258.

11. M. Mochizuki, R. Singh, T. Nguyen et al., Appl. Therm. Eng. 73 (2014) 699.

12. W. Fu, X. Li, X. Wu et al., Ann. Nucl. Energy 85 (2015) 346.

13. C. Ye, M.G. Zheng, M.L. Wang et al, Ann. Nucl. Energy 58 (2013) 124.

14. Y.S. Jeong and I.C. Bang, Appl. Therm. Eng. 96 (2016) 277.

15. Y.S. Jeong, K.M. Kim, I.G. Kim et al., Appl. Therm. Eng. 90 (2015) 609.

16. C. Wang, L. Liu, M. Liu et al., Ann. Nucl. Energy 109 (2017) 458.

17. K.M. Kim and I.C. Bang, Appl. Therm. Eng. 112 (2017) 560.
18. K. Ohashi, H. Hayakawa, M. Yamada et al., Prog. Nucl. Energy 32 (1998) 587.

19. C. Wang, J. Chen, S. Qiu et al., Ann. Nucl. Energy 103 (2017) 74.

20. K.K. Panda, I. V Dulera and A. Basak, Nucl. Eng. Des. 323 (2017) 376.

21. M.H. Kusuma, N. Putra, A.R. Antariksawan et al., Nucl. Eng. Technol. 49 (2017) 476.

22. M.H. Kusuma, N. Putra, S. Ismarwanti et al., Int. J. Adv. Sci. Eng. Inf. Technol. 7 (2017) 836.

23. M.H. Kusuma, Passive Cooling System in Nuclear Spent Fuel Storage Pool Using Heat Pipe, Dissertation, University of Indonesia (2017). (in Indonesian)

24. M.H. Kusuma, N. Putra, A.R. Antariksawan et al., Int. J. Therm. Sci. 126 (2018) 162.

25. W.N. Septiadi, N. Putra, M. Juarsa et al., Atom Indonesia 39 (2013) 24.

26. N. Putra, R. Saleh, W.N. Septiadi et al., Int. J. Therm. Sci. 76 (2014) 128.

27. T. Alizadeh and S. Azizi, Biosens. Bioelectron. 81 (2016) 198.

28. T. Tharayil, L.G. Asirvatham, M.J. Dau et al., Int. J. Heat Mass Transf. 106 (2017) 407.

29. W. Zhao, W. Chen, Y. Yue et al., Appl. Therm. Eng. 113 (2017) 481.

30. K.M. Kim and I.C. Bang, Int. J. Therm. Sci. 100 (2016) 346.

31. T. Tharayil, L.G. Asirvatham, V. Ravindran et al., Int. J. Heat Mass Transf. 93 (2016) 957.

32. E. Sadeghinezhad, M. Mehrali, M.A. Rosen et al., Appl. Therm. Eng. 100 (2016) 775.

33. M. Shafahi, V. Bianco, K. Vafai et al., Int. J. Heat Mass Transf. 53 (2010) 376.

34. A. Rosidi, N. Putra and M.H. Kusuma, IOP Conf. Ser.: Earth Environ. Sci. 105 (2018) 012030.

35. N. Putra, R.S. Ramadhan and W.N. Septiadi, Exp. Therm. Fluid Sci. 66 (2015) 13.

36. A. Alizadehdakhel, M. Rahimi and A.A. Alsairafi, Int. Commun. Heat Mass Transf. 37 (2010) 312.

37. Y.J. Park, H.K. Kang and C.J. Kim, Int. J. Heat Mass Transf. 45 (2002) 4655. 
38. T. Sukchana and C. Jaiboonma, Energy Procedia 34 (2013) 298.

39. H. Imura, K. Sasaguchi, H. Kozai et al. Int. J. Heat Mass Transf. 26 (1983) 1181.

40. B. Jiao, L.M. Qiu, X.B. Zhang et al., Appl. Therm. Eng. 28 (2008) 1417.

41. A. Amiri, R. Sadri, M. Shanbedi et al., Energy Convers. Manag. 92 (2015) 322.
42. A. Sözen, T. Menlik, M. Gürü et al., J. Exp. Heat Transf. 29 (2016) 337.

43. B. Fadhl, L.C. Wrobel and H. Jouhara, Appl. Therm. Eng. 60 (2013) 122.

44. E. Gedik, Energy Build. 127 (2016) 1096.

45. A. Sözen, T. Menlik, M. Gürü et al, Appl. Therm. Eng. 96 (2016) 330. 